\title{
THE IMPACT OF INFORMATION AND COMMUNICATION TECHNOLOGY ON HUMAN RESOURCES
}

\author{
Snežana Lj. Lazarević, \\ Jelena M. Lukić \\ Singidunum University, \\ Faculty of Physical Culture and Sports \\ Management, \\ Belgrade, Serbia
}

\begin{abstract}
:
Information and communication technology (ICT) has penetrated all the areas of our lives and work and has become their integral part. The success of modern organizations, regardless of their size and activity, is increasingly becoming molded by ICT. Thereby, numerous researches have attempted to identify what determines the success of using this technology. The conclusion is that the employees, as the most important resource of every organization, along with human knowledge, skills, potentials and abilities, are one of the crucial factors which determine the success of ICT application. The subject of this paper is the analysis of the impact of contemporary ICT on human resources. Along with the positive effects, the paper also presents negative implications of ICT on employees, which have started to appear in practice.
\end{abstract}

Key words:

human resources, information and communication technologies, employee knowledge and skills.

\section{INTRODUCTION}

One of the main change in organizations over the last couple of years is the growing use of information and communication technology (hereinafter ICT) [1]. Corroborating this is the fact that until recently, managers took no notice of decisions about introducing and applying ICT, while today this is not viable [2]. Until the 1980s, the primary role of technology was reflected in the automatization of business processes and reduction of their execution time. In the last decade of the $20^{\text {th }}$ and during the first two decades of the $21^{\text {st }}$ century, the impact of ICT, as a significant factor for designing an organization, has become the fundamental topic in both managerial and ICT literature $[3,4]$. Research has shown that ICT has generated new competencies, positions as well as a new nomenclature of positions [6]. Consequently, organizations are faced with numerous challenges and issues regarding the way of applying contemporary ICT, while the greatest changes are in the human resources (hereinafter: HR) area, that is, to be handled by the employees working with new technologies. Thus, the topic of this paper is to present the significance of ICT for an organization, and to indicate the role and significance of HR in its application. Along with the advantages, the paper also points to the key disadvantages, that is, the negative impact which ICT has on employees, which is increasingly more noticeable in practice.

\section{Correspondence:}

Snežana Lj. Lazarević

e-mail:

slazarevic@singidunum.ac.rs 


\section{THE SIGNIFICANCE OF ICT FOR CONTEMPORARY ORGANIZATIONS}

With the mass recognizing of the significance of information and communication technology by organizations in the last few decades, there increasingly appears the question whether ICT really transforms organizations and in which way [7]. Many people see in ICT a "magic wand" which can solve all the problems of an organization, overlooking the fact that the key to success is in total organizational change [8], that is, in a new organizational design which would enable using all ICT potential advantages [9]. Numerous research has confirmed that it is necessary to adapt the design of the organization, i.e.., its strategy, structure, processes, culture and $\mathrm{HR}$, for successful application of technology [4]. Also, it is important that the organization has the developed and informed work environment which represents a good technological support for redesigning work, business and information processes (workflow management) [5]. Through time it is shown that one of the key factors which determine the success of applying ICT are human resources, that is, knowledge, skills and abilities of employees [20, 21]. In order to perceive the significance of ICT for the organization, it is useful to examine Table I which considers the strategic impact of the portfolio development by applying ICT and its strategic impact on the existing operating systems [10].

\begin{tabular}{cccc}
\hline & & $\begin{array}{c}\text { Strategic impact on the } \\
\text { development portfolio by } \\
\text { applying ICT }\end{array}$ \\
\cline { 2 - 4 } & WEAK & STRONG \\
\hline $\begin{array}{c}\text { Strategic } \\
\text { impact } \\
\text { on the } \\
\text { existing } \\
\text { operating } \\
\text { systems }\end{array}$ & STRONG & Factory & Strategic \\
\cline { 2 - 4 }
\end{tabular}

\section{Table I. ICT strategic network}

Source: Adapted according to McFarlan F. W., and McKenney J. L. (1983). Corporate Information System Management: issues facing senior executives. Homewood: Dow Jones - Irwin.

Within the organizations where ICT has a minor influence or it is likely that it will have a minor influence in the future, its key activity is in supporting the existing business processes and activities which requires an average or below average investment and intermittent attention of the top management. In the organizations in which ICT has an essential relevance for the current business processes and activities but the impact on the strategic position of the organization is still not visible, its activity is of a factory nature. However, in the organizations in which ICT is considered to be crucial for the future survival and growth of the organization, it has the features of a driving force. The greatest impact of ICT is seen when the functioning and survival of an organization is affected by its application, due to which ICT is considered a strategic resource and an integral part of the organization [10]. ICT has a strategic significance due to numerous indirect effects embodied in new possibilities. The organizations which are aware and react to these possibilities ahead of others can obtain a significant advantage. In order to achieve this, organizations must carry out innovations in business practices or else, if they mechanically implement technology without making changes in the existing practices and processes, their investment will be ineffective [11].

The influences of ICT on an organization are numerous and can be seen on the operational level, the organization itself and business strategies [12]. The impact of ICT on the operational level is reflected on the products and services which increasingly obtain the element of information, markets which become fluid categories and the economy of production which is characterized by changes in the planned structure of costs. On the level of the organization, the impact of ICT is reflected in the influence of the purchasers (transferring of costs and consumer information); the influence of the suppliers by reducing their powers (by undermining or partition); substitution of products/services through numerous innovations (new products and value adding); the appearance of new competition via creating or destroying obstacles for market entry; rivalry through changing its basis (competition or cooperation). The impact of ICT on the level of the business strategy is reflected through cost efficiency, differentiation of product and focus.

The process of formulating a business strategy requires taking into consideration plentiful information from different sources. The data which has to be mainly considered are data of purchasers, regulations, data on competitors, inputs, needs of the stakeholders, limits of resources, and trends in their given branch. Organizations must be aware that all the collected data is correlated and they need to schedule their processing [13]. Great support can be found in the use of ICT considering that its primary role is to improve the collection, processing and exchange of information. 
The research of ICT impact on the competitve advantage of the organization started in the 1980s [14]. The widely accepted approach is that the application of ICT can lead to costs reduction, time reduction, the appearance of new channels of distribution, differentiating of products and services, as well as better understanding of purchasers' needs and desires [15]. Along with this, organizations can acquire numerous other advantages as ICT enables the following: collecting and processing of information at a significantly higher speed than in the past; making information accessible to all employees; enabling quicker access to information; stimulating the participation of staff in sharing and applying information and using information to adapt to the environment in a suitable manner [1].

It is very important for the organization to establish an ICT strategy which represents a set of decisions jointly brought by ICT and business management and which support and enable the realization of business strategies [16]. ICT strategy, along with the description of technology, must also include the connections and relationships between technology and business activities of the organization [18]. Thereby, it is obvious that formulated ICT strategy must be harmonized with the business strategy [17] and that the implemented ICT applications and infrastructure must support the strategic aims of the organization [19].

\section{THE IMPACT OF ICT ON HUMAN RESOURCES}

Contemporary organizations base their business success and competitive advantage on the strategic management of human resources. In that sense, it is noticeable that ICT turns out to be a strategic partner of human resource management (hereinafter: HRM), and the level of acceptance and implementation determines the structure of the e-HRM system. The application of the e-HRM concept implies a change in HRM activities [22], that is, with the development and introducing of new technologies in the organization, there occur relevant implications on HRM applied policies and practice in the organization. HRM activities such as planning human resources (through planning supply and demand) by applying contemporary quantitative methods and information systems, recruiting and selection of potential candidates via the Internet, social networks, the intranet and other (e-recruiting and e-selection), change of the nature of work - a more extensive designing of new jobs and redesigning existing ones, introducing new jobs, acquiring new knowledge and skills through professional training by applying e-learning and computer simulations - these are just some of the forms of HRM activities which have undergone transformations by applying ICT. Table II shows some of the technologies and their impact on HRM activities.

Technology

Impact on HRM

Web portals

Employees can independently update their data, follow and manage their benefits package.

Mobile web and wireless access to Used to help employees access the the Internet organization's HR activities.

Software for following activities on the Internet

Enables following employees to use the Internet for private purposes or monitors their work performance.

Data storage and analytical software

Assists HRM in monitoring HR systems and keep data accurate and updated.

Table II. The impact of ICT on HRM activities

Source: Adapted according to Dessler, G. (2007). Human Resource Management. New Jersey: Prentice Hall.

Certain authors stress that "technology was never a scarce resource" but rather a collection of managerial abilities needed to create a new value by applying this technology [24, p. 14]. Any organization which implements new technologies and new work processes must also have employees who can use them [25]. On the other hand, some consider that contemporary ICT will in the future lead to a radical work transformation and that the principle "I think, therefore, I produce" will prevail [26, p. 382], and that those employees with no ICT skills cannot expect respect from colleagues and supervisors [27, 28]. Also, with the influence of ICT, labor will become largely orientated towards teamwork, an increase of goods and services quality, meeting set deadlines, independence of staff, and a higher level of individual as well as team responsibility.

Research of the impact of technology on employees was carried out on various levels, starting from the entire organization, work groups and the level of the individuals. On the macro level, the key change was in the fact that top management came from technical science backgrounds or had substantial ICT skills [29] in contrast to the previous years, when social science degrees prevailed. A new work 
position is formed in the organizations -Chief Information Officer (CIO), with the role of correctly implementing ICT within an organization [19]. ICT has a large impact on the professional commitments of managers by making some routine and simple decisions automatic, enabling the delegating of rights and obligations to the middle and low-level management, whereas decision making can also be made by staff not in managerial positions. Many managers claim that ICT has enabled them to leave the office and do field work, and that they have more time for activity planning [29]. Along with this, ICT enables employees at all hierarchical levels to access the information needed for a more efficient planning process, decision making, coordination and control [1].

ICT is a significant challenge for employees [30], but they are the ones who to a large extent determine the destiny of ICT within an organization [31]. Primarily, what is expected from them is a high level of education which will help to acquire technical skills but also business knowledge. Employees must have the abilities and motivation for continuous learning and knowledge acquisition as well as a high degree of self-control, various interpersonal knowledge and skills and the analytical approach to problem solving. The additional challenges appear from the following facts: 1) new ICT possibilities grow exponentially, something that human abilities cannot follow; 2) human capital and the labor market are specific as they consist of individuals who have expectations, needs and desires; 3) ICT experts have different motivation factors and needs in comparison with other experts [32].

Along with the fact that ICT is necessary for the functioning of any organization, research has shown that in practice ICT has a positive impact on employee productivity, as well as satisfaction, efficiency, autonomy and flexibility [33].

One of the most significant changes is that employment is not fixed to a certain place and time as ICT has enabled the occurrence of virtual organizations and the self-styled organizations without borders. Employees can work from anywhere where there is a telephone, fax machine, e-mail and Internet access [33] and the key positive effects for the employees are time free from commuting, as well as a greater freedom in organizing work time and balancing private lives and business careers. Also, there are some negative effects of working from home, such as the impossibility of quality assessment of staff performance, a feeling of isolation due to the lack of physical contact and no development of loyalty and identification with the given organization [34].
The expression "infoworker," put forward in 1957, underscored that in the future those employees who can create new values for an organization based on information would prosper [35], and today it is experiencing a real renaissance. The prediction is that by 2020 , over $85 \%$ of the world population will be working as "infoworkers" [36, p. 77], and the hypotheses which [37] put forth in 1988 that employees will be forced to develop new skills and knowledge in order to work with new technologies as they imply a new way of thinking are totally confirmed today. Knowledge, which is increasingly permeating technological achievements, has replaced physical labor as a key component of economic development [38], while investing in human resources, human knowledge, skills and competencies is considered a key determinant of success and gaining a competitive advantage.

\section{NEGATIVE IMPACTS OF ICT ON HUMAN RESOURCES}

Certain weaknesses in ICT use have started to appear over time, along with numerous advantages. These weaknesses can be viewed from the aspect of technology, information security and work conditions [39]. The key negative consequences for employees are reflected via the influence of ICT on 5the a work environment. The ICT work environment may cause alienation and frustration of employees, as well as anxiety, stress, fear of job loss, and similar.

Many employees who use ICT to a large extent in their work place may undergo a loss of identity and the effects of alienation due to a specific feature of ICT - a lack of physical contact. Communication is carried out via e-mail without physical presence, and gives no possibility of viewing all the elements of non-verbal communication, gesticulation, or perceiving the tone of voice [1]. The reaction of the collocutor is unspecified until the message is answered, and even then there is no assurance that words have been chosen carefully and that the message replicates the essence [45].

Information technology and the Internet enable employees to be mobile, to work with co-workers from a distance and in all time zones, to do business in various forms and outside the traditional office environment [40]. In virtual organizations, employees are geographically dislocated and work from their homes without any physical contact, often worried that they are less valued and appreciated, that is, that they are "out of sight, out of mind" [41, p. 19]. Numerous research regarding those who 
work from home (in virtual organizations) haa indicated some of the aspects of the negative mindset which can be encountered. Primarily, these are the feelings of isolation, a lack of appreciation and respect, non-inclusion in all relevant decisions, difficulties in keeping step with the changes in the organization as well as receiving feedback in real time.

Information anxiety represents the frustration of employees due to impossibility to keep pace with the enormous amounts of data. The human brain has a limited capacity for memorizing, processing and applying information - psychologists claim that individuals cannot work concurrently with more than 5 to 9 information segments $[13$, p. 8]. Computers and ICT have significantly spread the power of information processing, thus enabling organizations to overcome the problem of the limitations of the human mind [13], but at the same time they have led to information anxiety due to presence of information from various social networks, smart phones, blogs, and e-mail. Consequently, various health problems can appear, such as insomnia, insufficient or poor sleep, tension and apprehension, loss of concentration, frequent headaches, etc. [29].

ICT can be important support for an organization's downsizing strategy, which has to a large extent impacted on the eliminating of certain work places and reducing the number of organizational levels. These processes have caused the loss of some jobs and working positions [42] which is the greatest fear for employees who fear that they may lose their jobs due to new technologies. On the other hand, some employees may undergo stress at work due to an incapability to manage new technologies. Also, employees who largely work with ICT may begin to feel the symptoms of digital Taylorism - as they are aware that managers can monitor them constantly via e-mails, telephones, logs, files, etc. [43].

A great problem for organizations and management is also using ICT for private purposes during work hours which can lead to reduction of efficiency of employees [44]. Overcoming this problem via a limited or terminated access to certain ICT segments (especially private e-mails and social networks) can result in employee dissatisfaction.

All these negative impacts of ICT are perceived only after its application and it is almost impossible to foresee them. However, in practice there is often a total disregard of the negative impacts as the attention of the management is directed exclusively towards the advantages of ICT [45].

\section{CONCLUSION}

The world around us has been changing lately due to the effect of ICT. It is very likely that in the following decades ICT will have a great impact on all areas of life and work. Contemporary organizations are increasingly applying ICT and finding ways to acquire a competitive advantage. The actual application of ICT requires numerous changes in human resources. One of the most significant factors thet determines the success of using ICT are human resources, that is, knowledge, skills and abilities of employees. Principally, analogously with the development and introduction of new technologies in organizations, there is a need for new work places, that is, new knowledge and skills. Also, the job descriptions and commitments of the employees undergo changes, as they attain a powerful weapon - ICT, which enables working from everywhere where computers and the Internet are available. ICT has intensified employee learning processes through various training sessions, retraining, skills and career development. However, in spite of numerous advantages of ICT application that are primarily reflected in the advancement of productivity and employee efficiency, some negative aspects have been identified in practice, such as alienation, negative psychological influences, information anxiety, stress, and fear of job loss. All these influences represent new challenges and tasks for human resource management.

\section{REFERENCES}

[1] Schermerhorn, J., Hunt, J., and Osborn, R. (2005). Organizational Behavior. New York: John Wiley \& Sons.

[2] Van Grembergen, W., and De Haes, S. (2009). Enterprise Governance of Information Technology, Achieving Strategic Alignment and Value. New York: Springer.

[3] Galbraith, J. (2014). Organization Design Challenges Resulting From Big Data. Journal of Organization Design, 3(1), 2-13.

[4] Daft, R. (2015). Organization Theory and Design (12th ed). Cengage Learning.

[5] Petković, M., Lazarević, S. (2012). Managing Interorganizational Relations: Design of Shared Services Centre. Management, 64, 55-67.

[6] Palvia, P., Palvia, S., and Roche, E. (1996). Global Information Technology and Systems Management: Key Issues and Trends. Nashua: Ivy League Publishing. 
[7] O'Callaghan, R. (2006). Technological Innovation in Organizations and Their Ecosystems. In W. Dutton, B. Kahin, R. O'Callaghan, and A. Wyckoff, Transforming Enterprise, The Economic and Social Implications of Information Technology (pp. 1-12). London: The MIT Press.

[8] Baets, W. (2005). Knowledge Management and Management Learning: Extending the Horizons of Knowledge-Based Management. New York: Springer.

[9] Swanson, E., and Ramiller, N. (1997). The Organizing Vision in Information Systems Innovation. Organization Science, 8(5), 458-474

[10] McFarlan, F., and McKenney, J. (1983). Corporate Information System Management: issues facing senior executives. Homewood: Dow Jones-Irwin.

[11] Brown, J., and Hagel, J. (2003). Letter for a debate. In N. Carr, IT Doesn't Matter?, An HBR Debate (pp. 1-17). Harvard Business Review.

[12] Parsons, G. (1983). Information technology: a new competitive weapon. Sloan Management Review, 25(1), 3-14.

[13] Ulwick, A. (1999). Business Strategy Formulation: Theory, Process, and the Intellectual Revolution. London: Quorum Books.

[14] Feeny, D., Ives, B., and Piccoli, G. (2003). Creating and Sustaining IT-Enabled Competitive Advantage. In J. Luftman, Competing in the Information Age, align in the sand (pp. 107-137). Oxford: Oxford University Press.

[15] Broadbent, M., McDonald, M., and Hunter, R. (2003). Letter. In N. Carr, IT Doesn't Matter?, An HBR Debate (pp. 1-17). Harvard Business Review.

[16] Boar, B. (2000). The Art of Strategic Planning for Information Technology. Indianapolis: Wiley.

[17] Earl, M. (2003). Integrating Business and IT Strategy, reframing the applications development portfolio. In J. Luftman, Competing in the Information Age, align in the sand (pp. 51-62). Oxford: Oxford University Press.

[18] Luftman, J. (2003). Strategic Alignment as a Process. In J. Luftman, Competing in the Information Age, align in the sand (pp. 381-394). Oxford: Oxford University Press.

[19] Ekman, P., and Dahlin, P. (2011). Management and Information Technology, Challenges for the Modern Organizations. London: Routledge.

[20] De Kok, A. (2016). The New Way of Working: Bricks, Bytes, and Behavior. In J. Lee, The Impact of ICT on Work (pp. 9-41). Springer.

[21] Lee, J. (2016). Drivers and Consequences in Transforming Work Practices. In J. Lee, The Impact of ICT on Work (pp. 71-95). Springer.
[22] Liang-Hung Lin (2011). Electronic human resource management and organizational innovation: The roles of information technology and virtual organizational structure. The International Journal of $\mathrm{Hu}$ man Resource Management, 22(2), 235-257.

[23] Dessler, G. (2007). Human Resource Management. New Jersey: Prentice Hall.

[24] Gurbaxani, V. (2003). Does IT Matter? An HBR Debate. Harvard Business Review, 1-17.

[25] Harreld, J. (1998). Building Smarter, Faster Organizations. In D. Tapscott, A. Lowy, and D. Ticoll, Blueprint to the digital economy, rating wealth in the era of e-business (pp. 60-77). New York: McGraw Hill.

[26] Castells, M. (2003). Kraj Tisućljeća, informacijsko doba, ekonomija, društvo i kultura, svezak III. Zagreb: Golden marketing.

[27] Gouillart, F., and Kelly, J. (1995). Transforming the Organization. New York: McGraw Hill.

[28] Drucker, P. (2002). Upravljanje u novom društvu. Novi Sad: Asee book.

[29] Turban, E., McLean, E., and Wetherbe, J. (2003). Informaciona tehnologija za menadžment, transformisanje poslovanja u digitalnu ekonomiju. Beograd: Zavod za udžbenike i nastavna sredstva.

[30] Morley, M., and Garavan, T. (1995). Current themes in organizational design: implications for human resource development. Journal of European Industrial Training, 19(11), 3-13.

[31] Benjamin, R., and Levinson, E. (1993). A Framework for Managing IT-Enabled Change. Sloan Management Review, 23-33.

[32] McLean, E., and Schneberger, S. (2003). Information Technology Human Resources Strategies. In J. Luftman, Competing in the Information Age, align in the sand (pp. 365-381). Oxford: Oxford University Press.

[33] Lee, J., and Park, J. (2016). Work Design Characteristics of Mobile-Intensive Workers: Implications for Future Work Design. In H. Lee, The Impact of ICT on Work (pp. 175-195). Springer.

[34] Petković, M., Orelj, A., and Lukić, J. (2014). Managing employees in a virtual enterprise. International Scientific Conference - Impact of Internet on Business Activities in Serbia and Worldwide (pp. 227-232). Belgrade: Singidunum University.

[35] Drucker, P. (1996). Landmarks of Tomorrow: A Report on the New. New Jersey: Transaction Publishers.

[36] Kreutzer, R., and Land, K. (2013). Digital Darwinism, branding and business models in jeopardy. New York: Springer.

[37] Zuboff, S. (1988). In the Age of the Smart Machine. New York: Basic Books. 
[38] Castells, M. (2000). Uspon umreženog društva, informacijsko doba: ekonomija, društvo i kultura, svezak I. Zagreb: Golden marketing.

[39] Pešić, V., and Lukić, J. (2014). The Negative Implications of Information and Communication Technology: Technical, Safety and Social Aspect. IV International Symposium Engineering Management and Competitiveness (pp. 435-440). Zrenjanin: Technical faculty Mihajlo Pupin.

[40] Đorđević Boljanović, J., Dobrijević, G. (2014). U traganju za fleksibilnošću: uticaj informacionih tehnologija na savremeno radno okruženje, International Scientific Conference - Impact of Internet on Business Activities in Serbia and Worldwide (pp. 233-236). Belgrade: Singidunum University.

[41] McCloskey, D., and Igbaria, M. (2003). Does „out of sight" mean „out of mind“? An empirical investigation of the career advancements prospects of virtual workers. Information Resources Management Journal, 16(2), 19-34.
[42] Dutton, W. (2005). Continuity or Transformation? Social and Technical Perspectives on Information and Communication Technologies. In W. Dutton, B. Kahin, K. O'Callaghan, and A. Wyckoff, Transforming Enterprise, The Economic and Social Implications of Information Technology (pp. 13-24). Cambridge: The MIT Press.

[43] Stanford, N. (2005). Organization Desing: The Collaborative Approach. Oxford: Elsevier ButterworthHeinemann.

[44] Caplan, S. (2006). Problematic internet use in the workplace. In M. Anadarajan, T. Teo, and C. Simmers, The Internet and Workplace Transformation (pp. 63-79). New York: Armonk.

[45] Mintzberg, H. (2015). Managing in the Digital Age: Over the Edge, available on www.druckerforum. org/blog/p=928, accessed 23.01.2016. 